\title{
励起光パルスの時空間制御による深部超解像イメージング技術
}

\author{
磯部圭佑 ${ }^{1,2}$, 戸田圭亮 ${ }^{1,3}$, 緑川 克美 ${ }^{1}$ \\ 1理化学研究所光量子工学研究領域 ( ₹351-0198 埼玉県和光市広沢2-1) \\ 科学技術振興機構 さきがけ (テ332-0012 埼玉県川口市本町4-1-8) \\ 埼玉大学大学院 理工学研究科 (テ338-8570 埼玉県さいたま市桜区下大久保255)
}

\section{Super-Resolution Deep Imaging by Spatio-Temporal Control of Excitation Pulses}

\author{
Keisuke ISOBE $^{1,2}$, Keisuke TODA ${ }^{1,3}$, and Katsumi MIDORIKAWA ${ }^{1}$ \\ ${ }^{1}$ RIKEN Center for Advanced Photonics, 2-1 Hirosawa, Wako, Saitama 351-0198 \\ ${ }^{2}$ JST, PRESTO, 4-1-8 Honcho, Kawaguchi, Saitama, 332-0012 \\ ${ }^{3}$ Graduate School of Science and Engineering, Saitama University, 255 Shimo-Okubo, Sakura, Saitama 338-8570
}

(Received June 8, 2016)

\begin{abstract}
Super-resolution optical microscopy that operates beyond the diffraction limit has become a powerful tool for investigating biological phenomena. However, it is difficult to achieve super-resolution imaging at deeper penetration depth in biological tissue. Since the in-focus signal intensity in super-resolution microscopy is very low, the in-focus signal is buried easily in the background light generated in out-offocus regions. Therefore, the background suppression techniques are essential for super-resolution deep imaging. Although nonlinear optical microscopy has the capability to suppress the out-of-focus background, the out-of-focus background generates in the deep imaging of scattering tissue and limits the observable imaging depth. We demonstrated not only the resolution enhancement but also the background suppression in nonlinear optical microscopy by spatio-temporal control of the excitation pulses.
\end{abstract}

Key Words: Ultrashort pulse, Nonlinear optics, Super-resolution imaging

\section{1. はじめに}

近年, 光の回折限界を超えた空間分解能をもつ超解像 顕微鏡 ${ }^{1-5)}$ は製品化され, 生物・医学分野における生命 現象解明のための重要な技術となっている。しかし, 生 体組織などの深部観察においては, 超解像イメージング を達成することは困難となっている，空間分解能を $N$ 倍 向上させると, 信号に寄与する体積は $N^{3}$ 倍減少する. そのため, 信号強度が $N^{3}$ 倍小さくなり, 観察している 焦点面以外において発生する背景光に埋もれやすくな る. 背景光を抑制するために, 全反射顕微鏡が用いられ ているが，試料表面の観察に制限される。一方，多光子 励起蛍光顕微鏡のように, 非線形光学過程を利用すれ ば, 背景光の発生を抑制できるため, 生体組織の深部イ メージングに有用である6,7)。しかし, 散乱や吸収の大 きな生体組織の深部観察においては, 多光子励起蛍光顕 微鏡を用いたとしても，背景光が発生するようになり， 観察可能な深さが制限されている ${ }^{8)}$. また, 生体組織の 屈折率分布は一様でないため, 波面歪みによって, 空間 分解能が劣化することも問題である. 最近, 背景光 ${ }^{9-17)}$ や波面歪み ${ }^{18,19)}$ の問題を解決するための技術開発が進ん でいる. また, 超解像顕微鏡と非線形光学顕微鏡を融合
させ，深部観察において，超解像イメージングを達成す る試みも始まりつつある ${ }^{17,20-22)}$. 本論文では, 深部イ メージングにおける背景光の問題を解決するための技術 を紹介するとともに, 著者らが開発している深部超解像 イメージング技術について解説する.

\section{2. 背景光抑制・除去技術}

多光子励起蛍光顕微鏡では, Fig. 1(a)のように, 高い 開口数の対物レンズを用いて，励起光を空間的にきつく 集光する. $n$ 光子励起蛍光強度は励起光強度の $n$ 乗に比例 するため, 蛍光強度が高い領域を, 励起光強度の高い集 光点近傍のみに局所化できる ${ }^{6,7)}$. しかし, Fig. 1(b)のよ うに，散乱や吸収による試料内における光の減衰係数 $\alpha$

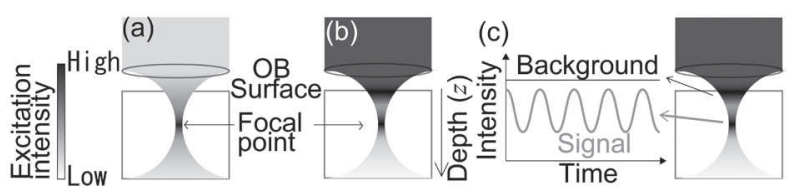

Fig. $1(\mathrm{a}, \mathrm{b})$ Excitation intensity distribution (a) without and (b) with scattering and absorption losses; OB: Objective lens. (c) Spatio-temporal modulation. 
の大きな試料の深部観察では, 集光点近傍以外で発生す る蛍光強度を無視できなくなる ${ }^{8)}$. 侵入長 $Z$ が媣くなる と, 試料表面から集光点に到達するまでに, 励起光パ ワーは $\exp (-\alpha z)$ 倍減衰する。 そのため, 集光点におい て発生する蛍光強度を維持するためには，入射光パワー を $\exp (\alpha z)$ 倍増加させる必要がある。しかし, 試料表面 の励起光強度は入射光パワーの増加分だけ増加する。し たがって, 試料表面近傍で発生する $n$ 光子励起蛍光強度 はexp $(n \alpha z)$ 倍増加する。そそのため, 試料表面近傍で発生 した蛍光強度が集光点近傍で発生する蛍光強度に等しく なると，それ以上の深さは基本的には観察できない．

試料表面近傍に㧍ける背景蛍光の発生を抑制できれば, 観察可能な深さを向上できる. 最も簡易的な手法として は, 励起光の波長を減衰係数 $\alpha$ のさな波長にすること である ${ }^{9,10)}$. 生体組織内に扔ける吸収損失が最も小さな 波長带域は1.08 $\mu \mathrm{m}$ であるが, 散乱損失と合わせた光損 失が最も小さな波長帯域は $1.3 \mu \mathrm{m}$ や $1.7 \mu \mathrm{m}$ である。これ らの波長带域を用いた 2 光子励起蛍光顕微鏡 起蛍光顕微鏡(1)によって, 観察可能な深さをマウス脳深 部の海馬領域(約 $1.5 \mathrm{~mm}$ )まで向上させている。また, 減衰係数 $\alpha$ は試料の状態にも依存する。生きたままの状 態で，イメージングのための開頭手術に打ける出血など もなければ，試料の透明度は高い。そのような場合に は, 十分なレーザー光パワーがあれば, $1 \mu \mathrm{m} の$ 波長で も, マウス脳深部の海馬領域まで観察することが可能で ある ${ }^{23,24)}$ 。したがって, 媣部イメージングでは, 試料の 透明度を保つ手術技術も必要である。

励起光の強度分布を時空間制御することによって, 発 生した背景光を積極的に除去する手法も開発されてい る. Fig. 1(c)のように, 試料表面に扔いて発生する光強 度は変調せず, 集光点に扔いて発生する光強度の久変調 すると, 試料表面で発生する背景光と集光点で発生する 信号光を分離することができる，例えば，収差のある励 起光と収差のない励起光によって取得した 2 光子励起蛍 光像の差から背景光のない蛍光像が抽出できる11). ま た, 焦点面近傍でのみ空間的に重なる複数のビームを位 相変調すると, 干渉効果によって, 集光点近傍の空間強 度分布のみ変調できる ${ }^{22}$. 変調された信号成分をロック イン検出すれば，背景光が除去された蛍光像を取得でき る.この手法は共焦点顕微鏡で実現された手法である が，多光子励起蛍光顕微鏡への応用が可能である。ま た, Fig. 2(a)のような2波長パルスの空間重なり変調 (Spatial Overlap Modulation: SPOM)によっても, 背景光 の除去が可能である ${ }^{13)}$. 2波長パルスが空間的に重なっ たときにしか発生しない非線形光学過程を用いれば, 集 光点近傍で発生する光強度の久変調できる。この手法で は, 2 波長励起の非縮退 2 光子励起蛍光, 和周波発生, 誘 導ラマン散乱など様々な非線形光学顕微鏡 (Nonlinear Optical Microscopy: NOM) へ応用可能である.SPOMNOMでは, 背景光の除去と同時に空間分解能も向上可 能である ${ }^{13)}$.SPOM-NOMで発生する非線形信号光強度 は，2波長パルスの強度積に比例する．Fig. 2(b)のよう

に, パルス $1 の$ 集光点を固定し，パルス2の集光位置を $\pm \delta$

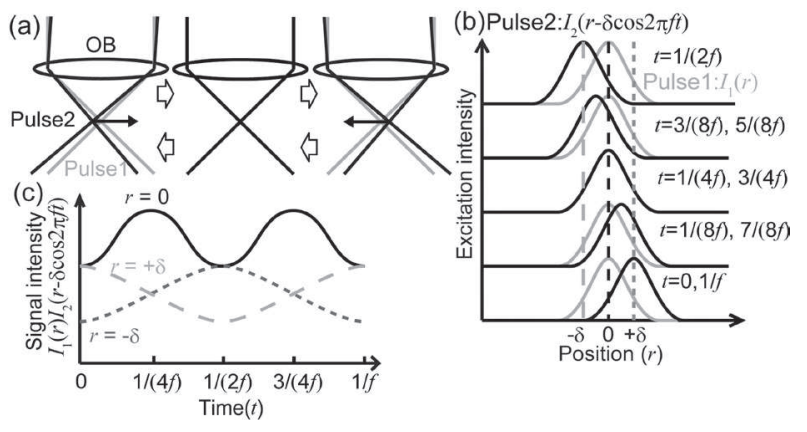

Fig. 2 (a) SPOM. (b) Transition of the intensity distributions of the two pulses in SPOM. (c) Variation of intensity product of the two-pulses by SPOM.

だけ周波数 $f て ゙$ 変調すると， 2 波長パルスの強度積の時 間変化はFig. 2 (c)のように位置によって異なる。このよ うな変調信号の周波数と位相が, 集光スポット内の位置 に依存することを利用して, SPOM-NOMでは, 空間分 解能を向上させることが可能である。

広視野多光子励起蛍光影微鏡に扔ける背景光を抑制す る技術も開発されている. Fig. 3(a)のように, 回折格子 などの分散素子によって分光されたフェムト秒パルスを 集光すると，パルス幅は光軸方向に沿って変化する。こ のような時空間集光 (Temporal Focusing: TF) 技術は, 回 折限界まできつく空間集光するのではなく, 広視野を照 明するために用いられる。焦点面では，全ての波長成分 が空間的に重なり合うため, フーリエ変換限界のフェム 卜秒パルスとなる。 しかし, 焦点面から光軸方向に離れ るほど，空間的に重なり合うスペクトル帯域幅が狭くな るため, ピコ秒やナノ秒までパルス幅が伸びる。した がって, 高いピーク強度を必要とする多光子励起蛍光の 発生を集点面近傍に局所化できる ${ }^{14)}$ ，そのため, 励起光 のレーザー走査を一切行うことなく, 蛍光断層像を取得 できる、しかし，レーザー走査型の多光子励起蛍光顕微 鏡と同様に, 観察深さが深くなると, 焦点面以外で発生 する蛍光が背景光となる.

広視野蛍光顕微鏡では，集点面近傍以外で発生する背 景光とは別の背景光の問題もある. 広視野顕微鏡では, 焦点面を2次元検出器に結像する必要がある. しかし, 焦点面で発生した蛍光が試料内部で散乱すると, 全ての ピクセルに拡がって背景光となる. 広視野 1 光子励起蛍 光顕微鏡の焦点外蛍光と散乱蛍光の両方を除去可能な手 法として構造化照明法が開発されている ${ }^{15}$. 構造化照明 法では, Fig. 3(b)のように, 焦点面近傍でのみ, 励起光

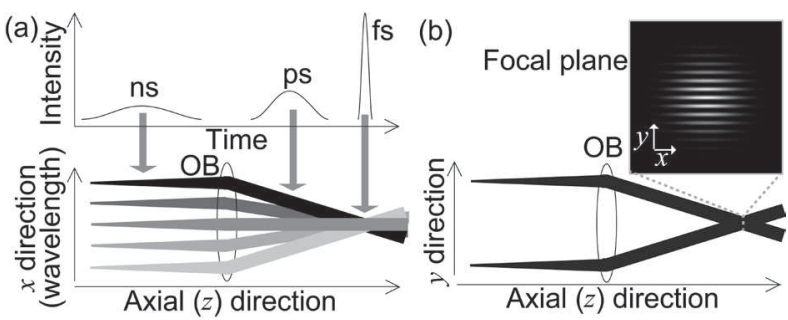

Fig. 3 (a) Temporal focusing. (b)Structured illumination. 
を重ね合わせ，干渉させる。このとき，干渉縞が発生す るのは, 焦点面近傍のみであり, Fig. 1(c)のような時空 間変調が可能である。 また, 検出器上に縞を結像できる のは, 弾道蛍光のみで, 散乱蛍光は, 結像できない, そ のため, 縞成分を抽出すると, 焦点外蛍光と散乱蛍光の 両方を除去できる。この手法を時空間集光法と組み合わ せることによって, 広視野 2 光子励起蛍光顕微鏡の背景 光除去に成功している ${ }^{16,17)}$. 構造化照明法は超解像イ メージングにも応用可能な手法 ${ }^{3,4}$ である。構造化照明 法では, 空間周波数 $k_{0}$ の強度分布 $I_{\mathrm{ex}}(\mathrm{r})=I_{0}\left\{1+\cos \left(k_{0} r\right)\right\}$ をもった励起光によって, 試料が照明される. 試料上に 扔ける蛍光発光分布は, 励起光強度と試料の分布の積で 表される。ここで, 試料の分布 $S(r)$ は様々な空間周波数 成分 $k_{\mathrm{s}}$ の重㸚合わせによって表現できる. 各空間周波数 成分 $k_{\mathrm{s}}$ は, 構造化照明法を用いると, $k_{\mathrm{s}}-k_{0}$ と $k_{\mathrm{s}}+k_{0}$ に周 波数変換される. 空間周波数が下方変換されることに よって, 光学影微鏡における光学伝達関数の遮断周波数 $k_{\mathrm{c}}$ より， $k_{0}$ だけ高い試料の空間周波数成分 $k_{\mathrm{c}}+k_{0}$ まで検出 できるようになる. 検出後, 元の空間周波数 $k_{s}$ に戻すこ とによって, 超解像が得られる.

\section{3. 深部超解像イメージング技術}

2014年にノーベル化学賞を受賞したSTED (Stimulated Emission Depletion) 顕微鏡 ${ }^{1)}$ PPALM (Photo-Activated Localization Microscopy $)^{22}$ などの超解像技術と, 前節で述べ た背景光を抑制，または除去する技術を組み合わせた深 部超解像イメージング技術が報告されている。焦点面以 外で背景蛍光が発生することを抑制するために, STED 顕微鏡は, 空間集光の 2 光子励起法と ${ }^{20,21)}$, 広視野顕微 鏡であるPALM ${ }^{22)}$ は時空間集光法との融合が実現してい る。著者らは, 背景光の発生を抑制するだけでなく, 発 生した背景光の除去も積極的に行うために, 構造化照明 法と時空間集光法を融合させた干涉時空間集光 (Interferometric Temporal Focusing: ITF) 顕微鏡を開発している ${ }^{177}$. また，著者らが提案するSPOM-NOMも，背景光の抑制 と除去が可能な超解像イメージング技術である。ここで は，SPOM-NOMとITF顕微鏡を用いたイメージング例に ついて紹介する。

\subsection{SPOM-NOM}

SPOM-NOMの実験光学系は, 一般的な2波長励起の非 線形光学顕微鏡に, 空間重なり変調のための偏向器を挿 入しただけである ${ }^{13,25,26)}$. Fig. 4(a)に示すように, SPOM-NOMの点像分布関数の半值全幅は, 従来の 2 光子 励起蛍光顕微鏡に対して1.6倍狭くなる. 従来の和周波 発生顕微鏡とSPOM-NOMによって取得したグラニュー 糖粉末の和周波発生像をFig. 4(b) と (c) に示す. SPOMNOMでは, 従来の和周波発生顕微鏡では観察できてい ない小さな構造が可視化されている. グラニュー糖粉末 間は空気であり, 波面歪みの影響は大きい。しかし， SPOM-NOMでは, 光軸に金直な面内 $(x)$ 方向だけでな く, 光軸 $(z)$ 方向の空間分解能も向上しているのがわか

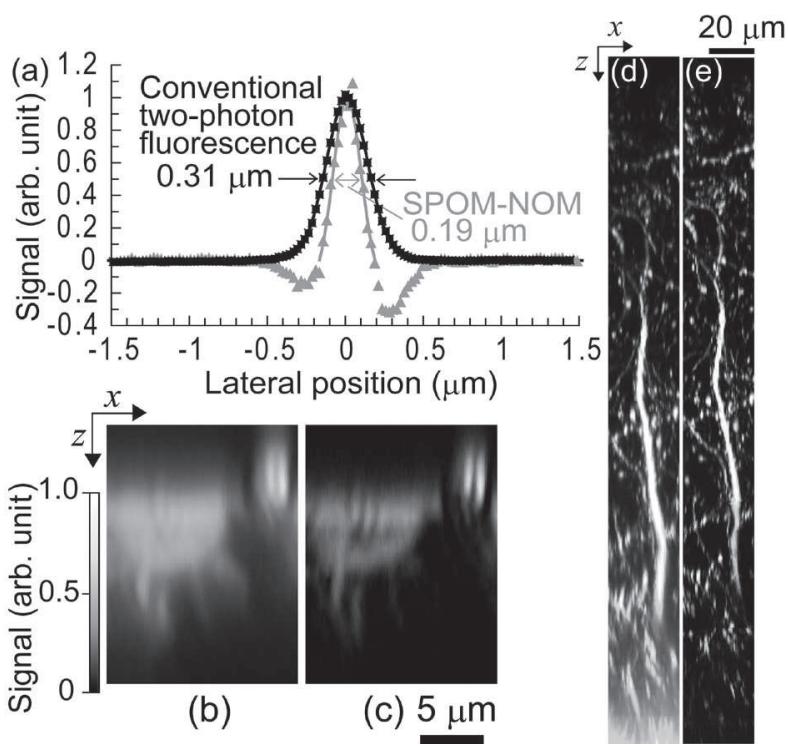

Fig. 4 (a) Point spread function of conventional twophoton fluorescence microscopy (square) and SPOM-NOM (triangle). ${ }^{13)}$ (b, c) Sum frequency generation (SFG) images of granulated sugar pounded in a mortar obtained by (b) conventional SFG microscopy and (c) SPOM-NOM. ${ }^{25)}$ (d, e) Maximum-intensity y projections of the image stacks of fixed mouse brain tissues, which express a YFP in a subset of neurons, obtained by (d) conventional TPEF microscopy and (e) SPOMNOM. ${ }^{13}$

る. Fig. 4 (d), (e)にホルマリン固定したマウスの脳組 織の 2 光子励起蛍光像を示す. 媣部における背景蛍光は, 従来の 2 光子励起蛍光顕微鏡では強い。これは, 光の減 衰係数が生きているマウスの脳組織に比べると約 3 倍高 い170 $\mathrm{cm}^{-1}$ であったことが原因である。しかし，SPOMNOMでは背景蛍光が抑制できていることがわかる。 ま た, 従来の 2 光子励起蛍光顕微鏡では, 波面歪みによっ て梁部に扔ける空間分解能が劣化しているにもかかわら ず，SPOM-NOMでは深部でも空間分解能が高いことが わかる

\subsection{ITF顕微鏡}

ITF顕微鏡では, 時空間集光のための分散素子と, 構 造化照明のためのビームスプリッターが必要であるた め, 実験光学系が複雑である ${ }^{17}$. ᄂ しかし，Fig. 5に示す ように，デジタルミクロミラーデバイス (DMD)を用い ることによって，光学系を簡易化できる，著者らの使用 しているDMDは7.6 $\mu \mathrm{m} \times 7.6 \mu \mathrm{m}$ のイクロミラー100万 個以上で構成されている。. 各ミラーの角度は \pm 12 傾き, 顕微鏡への光路 (ON状態) とビームダンパーへの光路 (OFF状態)を $230 \mu \mathrm{s}$ で切り替えることが可能である. 全 てのミラーがON状態のとき, 格子定数がミラー間隔, ブレーズ角がミラーの傾きとなる位相型ブレーズド回折 格子となる。 そのため, ON状態のミラー群は, 時空間 集光のための分散素子として働き，フェムト秒光パルス を分光するために用いることができる，ただし，格子定 


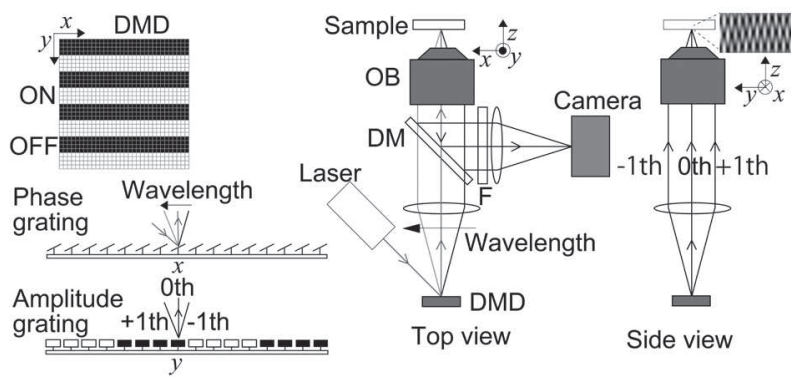

Fig. 5 Experimental setup for an ITF microscope using a DMD. OB: Objective lens, DM Dichroic mirror, F: Bandpass filter.

数が波長よりも大きい(約10倍)ため, 高次の回折光を用 いる必要がある。著者らの構成では，4次の回折光を用 いて, 回折効率 $56 \%$ が得られた。 また, ON状態とOFF状 態のミラー群を周期的に配置すると，格子定数がミラー 群の周期となる振幅型の回折格子となる。この振幅型回 折格子は, 格子定数が波長よりも十分大きい(約100倍) ため, 構造化照明のためのビームスプリッターとして働 き, 0 次光と \pm 1 次光を発生させるために用いることがで きる. したがって, 試料と2次元検出器の共役な位置に DMDを配置することによって，簡単にITF顕微鏡が作製 できる，また，DMDを用いた構造化照明では，2光束干 渉ではなく, 3光束干渉となる. そのため, 光軸に垂直 な面内方向だけでなく, 光軸方向にも干渉縞を発生させ ることが可能である。したがって, 3次元空間分解能の 向上が可能である。また, 背景光を除去するためには, 縞成分のみを抽出して, 超解像の画像を再構築する必要 がある ${ }^{17)}$.

ITF顕微鏡では, 広視野で同時に多光子励起を行う必 要があるため, 光源には, 高パワーフェムト秒レーザー
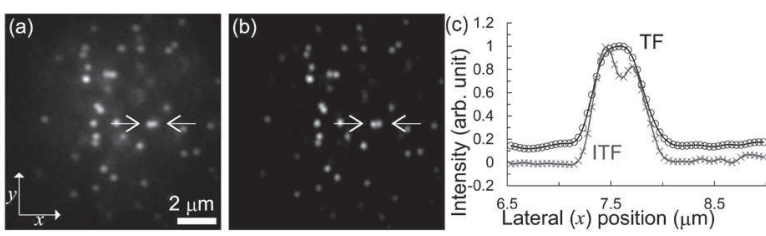

(d) Cover glass Rhodamine B
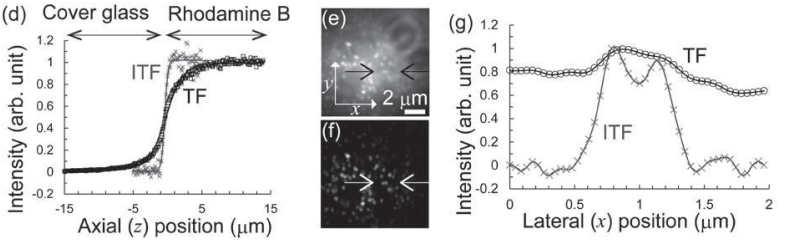

Fig. $6(\mathrm{a}, \mathrm{b})$ Fluorescence images of 200-nm fluorescent beads obtained by (a) TF and (b) ITF microscopies. (c) Intensity profile indicated by arrows in Figs (a) and (b). (d) Signal intensity distribution along the axial direction near the interface between the cover glass and the Rhodamine B solution. (e, f) Fluorescence images of 200-nm fluorescent beads in the tissue-like phantom obtained by (e) TF and (f) ITF microscopies. (g) Intensity profile indicated by arrows in Figs (e) and (f).
が必要である．著者らは，Yb添加ダブルクラッドファイ バを用いたチャープパルスファイバ増幅器(波長1060 nm, パルス幅80 fs, 繰返し周波数 $200 \mathrm{kHz}$ ，パルスエネル ギー1 $\mu \mathrm{J})$ を作製し，光源として用いている.

TF顕微鏡とITF顕微鏡を用いて取得した直径 $200 \mathrm{~nm}$ の 蛍光ビーズの2光子励起蛍光像をFig. 6(a), (b)に示す. また, Fig. 6(a)，（b）中の矢印で示した位置の強度分布 をFig. 6 (c) に示す。TF顕微鏡では2つのビーズが分解で きていない，一方，ITF顕微鏡では，はっきりと2つに分 解でき，ビーズ間距離は約 $260 \mathrm{~nm}$ であることがわかる. また，ローダミンBの溶液とカバーガラスの境界近傍に おける光軸方向の蛍光強度をFig. 6(d) に示す. Fig. 6(d) の曲線の差分から光軸方向の空間分解能が3次元構造化 照明法により約3.5倍改善できていることがわかる。直 径 $200 \mathrm{~nm}$ と $2 \mu \mathrm{m}$ の蛍光ビーズをアガロースゲルに封入 した模擬生態組織の2光子励起蛍光像をFig. 6(e), (f) に 示す. $2 \mu \mathrm{m}$ の蛍光ビーズは背景蛍光を発生させるとと もに，散乱体としても作用している。また，Fig. 6(e)， (f) 中の矢印で示した位置の強度分布をFig. $6(\mathrm{~g})$ に示 す. 背景光の除去と同時に空間分解能が向上しているこ とがわかる。

\section{4. おわりに}

本稿では, 深部イメージングにおいて問題となる背景 光を抑制・除去する技術について紹介した。背景光の抑 制・除去技術を超解像技術と融合させることによって, 深部超解像イメージングが可能になることも示した。本 稿では紹介しなかったが, 深部イメージングにおいて は，光源であるレーザー技術や蛍光プローブ技術の発展 も大きく貢献している．多光子励起蛍光顕微鏡による深 部イメージングでは, 繰返し周波数 $80 \mathrm{MHz}$ のフェムト 秒発振器を用いた場合, 試料表面において数百 $\mathrm{mW}$ の平 均パワーが必要になる。顕微鏡などの透過率を考える と, 平均出力パワー数Wのフェムト秒発振器が必要であ る. $0.8 \mu \mathrm{m}$ や $1 \mu \mathrm{m}$ の波長帯域では, チタンサファイア レーザーやYbファイバレーザーなどが市販され，生 物・医学の分野でも容易に使用可能になっている。 ま た，試料透過性の高い近赤外領域の蛍光プローブも開発 され，深部イメージングに応用され始めている。 今後, $1.3 \mu \mathrm{m}$ や $1.7 \mu \mathrm{m}$ の波長帯域でも, 平均出力数Wのフェム ト秒レーザーが市販されるようになるとともに，蛍光プ ローブ技術も発展すれば, 生物・医学の分野での深部イ メージングへの応用が拡がっていくと期待できる。ま た，深部イメージングでは，波面歪みによって空間分解 能が劣化することも問題であるが，それを補償する技術 も進展している ${ }^{18,19)}$. 今後, レーザー技術, 蛍光プロー ブ技術，波面補償技術，超解像技術，背景光抑制・除去 技術の相互発展によって, 深部超解像イメージングの性 能のさらなる向上が期待できる。 


\section{謝 辞}

本稿で紹介した筆者らの研究成果の一部は, 理化学研 究所脳科学総合研究センターの河野弘幸博士, 熊谷 安希子博士, 宮脇 敦史博士, 東京理科大学理工学部物 理学科の須田 亮教授, 慶應義塾大学理工学部電子工学 科の神成 文彦教授との共同研究の成果である。本研究 の一部は, 公益財団法人住友財団, 公益財団法人コニカ ミノルタ科学技術振興財団, 公益財団法人倉田記念日立 科学技術財団, 公益財団法人サントリー生命科学財団, 公益財団法人 光科学技術研究振興財団からの助成を受 けて行われた。ここに深く感謝の意を表します。

\section{参考文献}

1) S. W. Hell and J. Wichmann: Opt. Lett. 19 (1994) 780

2) E. Betzig: Opt. Lett. 20 (1995) 237.

3) M. G. L. Gustafsson, J. Microsc. 198 (2000) 82.

4) R. Heintzmann, T. M. Jovin, and C. Cremer: J. Opt. Soc. Am. A 19 (2002) 1599.

5) Diaspro: Nanoscopy and Multidimensional Optical Fluorescence Microscopy (Francis and Taylor, 2010).

6) W. Denk, J. H. Strickler, and W. W. Webb: Science 248 (1990) 73.

7) E. E. Hoover and J. A. Squier: Nature Photon. 7 (2013) 93.

8) P. Theer and W. Denk: J. Opt. Soc. Am. A 23 (2006) 3139.

9) D. Kobat, M. E. Durst, N. Nishimura, A. W. Wong, C. B. Schaffer, and C. Xu: Opt. Express 17 (2009) 13354.
10) N. G. Horton, K. Wang, D. Kobat, C. G. Clark, F. W. Wise, C. B. Schaffer, and C. Xu: Nature Photon. 7 (2013) 205.

11) A. Leray and J. Mertz: Opt. Express, 14 (2006) 10565.

12) N. Chen, C.-H. Wong, and C. J. R. Sheppard: Opt. Express 16 (2008) 18764.

13) K. Isobe, H. Kawano, T. Takeda, A. Suda, A. Kumagai, H. Mizuno, A. Miyawaki, and K. Midorikawa: Biomed. Opt. Express 3 (2012) 1594.

14) D. Oron, E. Tal, and Y. Silberberg: Opt. Express 13 (2005) 1468.

15) M. A. A. Neil, R. Juskaitis, and T. Wilson: Opt. Lett. 22 (1997) 1905.

16) H. Choi, E. Y. S. Yew, B. Hallacoglu, S. Fantini, C. J. R. Sheppard, and P. T. C. So: Biomed. Opt. Express 4 (2013) 995.

17) K. Isobe, T. Takeda, K. Mochizuki, Q. Song, A. Suda, F. Kannari, H. Kawano, A. Kumagai, A. Miyawaki, and K. Midorikawa: Biomed. Opt. Express 4 (2013) 2396.

18) N. Ji, D. E. Milkie, and E. Betzig: Nature Meth. 7 (2010) 141.

19) K. Wang, W. Sun, T. Richie, B. K. Harvey, E. Betzig, and N. Ji: Nat. Commun. 6 (2015) 7276.

20) G. Moneron and S. W. Hell: Opt. Express 17 (2009) 14567.

21) J. B. Ding, K. T. Takasaki, and B. L. Sabatini: Neuron 63 (2009) 429.

22) A. Vaziri, J. Tang, H. Shroff, and C. V. Shank: Proc. Natl. Acad. Sci. USA. 105 (2008) 20221.

23) R. Kawakami, K. Sawada, A. Sato, T. Hibi, Y. Kozawa, S. Sato, H. Yokoyama, and T. Nemoto: Sci. Rep. 3 (2013) 1014.

24) R. Kawakami, K. Sawada, Y. Kusama, Y.-C. Fang, S. Kanazawa, Y. Kozawa, S. Sato, H. Yokoyama, and T. Nemoto: Biomed. Opt. Express 6 (2015) 891.

25) K. Isobe, H. Kawano, A. Kumagai, A. Miyawaki, and K. Midorikawa: Biomed. Opt. Express 4 (2013) 1937.

26) K. Isobe, H. Kawano, A. Suda, A. Kumagai, A. Miyawaki, and K. Midorikawa: Biomed. Opt. Express 4 (2013) 1548. 